\title{
Corrosive Induced Gastric Outlet Obstruction in Children
}

\author{
Ali Ansar ${ }^{1}$, Faruquzzaman ${ }^{1 *}$, Rahman Masfiqur ${ }^{1}$, Boksh Zahid ${ }^{1}$, Kibria Golam ${ }^{1}$, Sharifuzzaman ${ }^{1}$ and Hasina \\ Kaniz $^{2}$
}

${ }^{1}$ Department of Pediatric Surgery, Jessore Medical College, Bangladesh

${ }^{2}$ Department of Pediatric Surgery, Dhaka Medical College, Bangladesh

Submission: April 12, 2018; Published: May 16, 2018

"Corresponding author: Faruquzzaman, Department of Pediatric Surgery, Jessore Medical College, Bangladesh, Email: drfaruquzzaman@yahoo.com

\begin{abstract}
Background: Patients with gastric outlet obstruction, secondary to corrosive ingestion admitted in pediatric surgery department from January 2005 to June 2016. Most common corrosive was sulphuric acid and it was taken accidentally by pediatric groups. Besides this, hydrochloric acid, carbolic acid, sodium hydroxide, sodium hypochlorite, sodium carbonate etc are also common. Following conservative treatment, patients developed gastric outlet obstruction within 12 to 20 days. Surgery was performed to relief obstruction.

Patients and Methods: Our study is a retrospective study on gastric outlet obstruction following corrosive ingestion. 8 patients were admitted in the department of pediatric surgery from January 2005 to June 2016. H/O of corrosive intake, nature, time, type of injury, treatment and period of development were gastric outlet obstruction were taken. For diagnosis of gastric outlet obstruction endoscopy \& barium meal $\mathrm{X}$-ray of upper GIT were done. Pre-operative fluid and electrolyte imbalances, anemia and malnutrition were corrected. Gut preparation was also done before operation. All patients were operated under endo-tracheal general anaesthesia. Post operative period were uneventful. Feedings were started on $5^{\text {th }}$ to $6^{\text {th }}$ POD by initially liquid, then gradually semisolid to normal. Post operative complications were recorded. Patients were discharged on $8^{\text {th }}$ POD. All patients were followed up 6 months to 1 year. During follow up general conditions of patients, serum albumin level, $\mathrm{Hb} \%$, and endoscopy of upper GIT were performed.
\end{abstract}

Results: Total number of patients in our study was eight, Male-6 \& Femal-2, mean age about 6 years, ranging from 3 to 10 years, and intake corrosive accidentally. Period of development of was gastric outlet obstruction about 15 days, range 12 to 20 days. Initially complications were odynophagia and dysphasia. But latter develop with gastric outlet obstruction within 12 to 20 days. Mean operative time 1.5 hours. Procedure was posterior gastro-jejunostomy. No significant post-operative complications were encountered. On follow-up, all patients were being well. General conditions, appetite, weight gain were better. No re-do operation were performed.

Conclusion: Avoidable circumstances can be reduced by cautiousness in family as well as in every aspect of our community, like terrorism prevention in our country. Early surgical intervention gives excellent result. Gastrojejunostomy is a very safe operation with minimum morbidity and excellent long-term outcome.

Keywords: Pyloric stenosis; Gastric outlet obstruction; Corrosive ingestion; Gatro-jejunostomy

\section{Introduction}

Corrosive ingestion is not uncommon in developing countries like Bangladesh. Ingestion may be either by accidental, suicidal or homicidal. Again corrosive may be either acid or alkali. Corrosive ingestion is an important medical and social problem due to associated early and long-term complications, including bleeding, perforation, systemic complications (renal insufficiency, hepatic dysfunctions and DIC), oesophageal stricture, fistula, gastric outlet obstruction and cancer. GOO is a squeal of inflammation i.e. scaring, cicatrisation and ultimately stricture formation at pylorus and antrum of stomach. Initially patients usually managed conservatively. Attempts at neutralizing the acids or alkalis are ill-advised and the resulting exothermic reaction from the neutralization process may do more harm than good. Similarly, there is not much role for measures to dilute the corrosive with milk, water and so forth, as the definitive extent of the injury is determined within minutes after ingestion. Many of patients may develop GOO within 12 to 20 days. In our study eight patients were included. All are pediatric age groups. They had been ingested acid accidentally i.e. they intake it as beverage. 
Initially they were treated conservatively but developed GOO latter on. For this complication surgery was performed. After surgery 6 months to 1 year follow up were given.

\section{Materials and Methods}
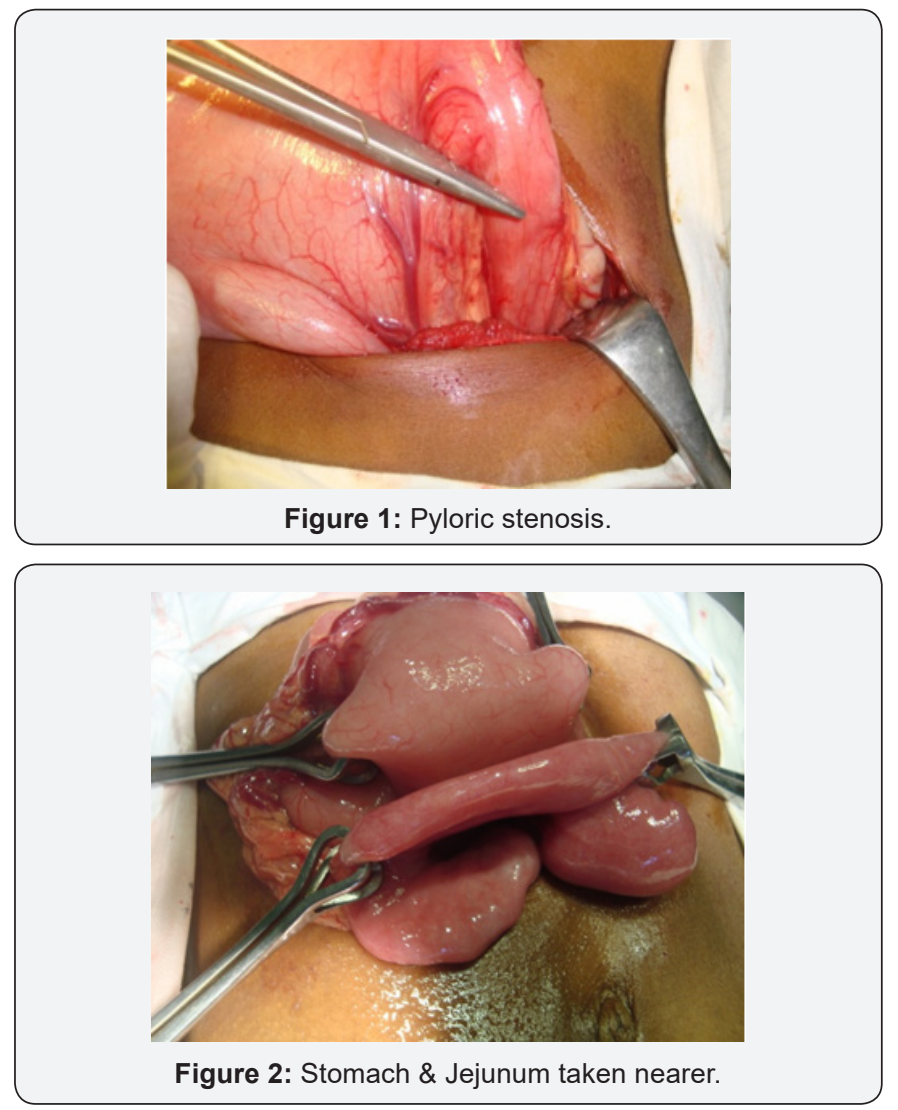

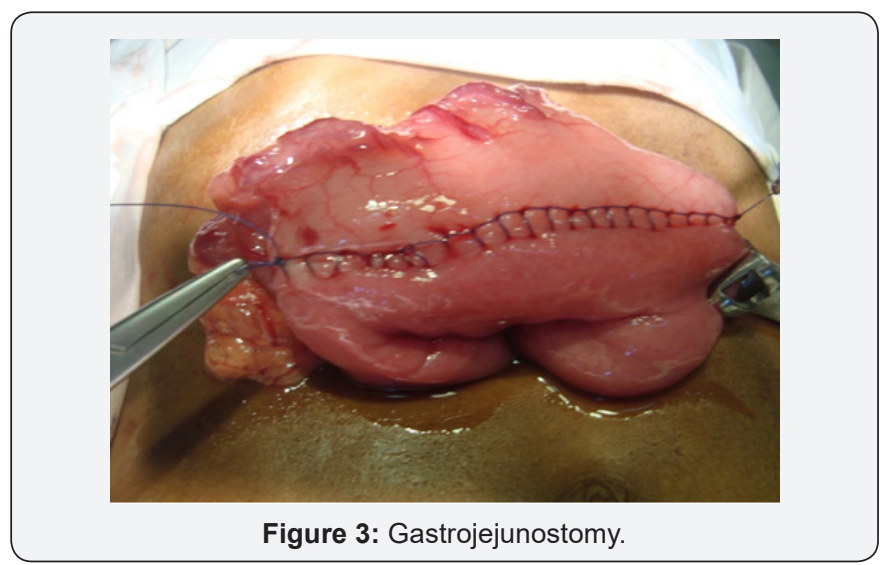

Our study was G00, as sequelae of corrosive ingestion. It is a retrospective study on patients of GOO following corrosive ingestion. Eight patients were admitted in the department of pediatric surgery from January 2005 to June 2016. H/O of corrosive intake, nature, time, type of injury, treatment period of development GOO and Operation were taken. For diagnosis of GOO endoscopy \& barium meal X-ray of upper GIT were done. Pre-operative correction of anemia, improvement of nutritional status, correction of fluid and electrolytes imbalances was done. Gut preparation were also done before operation. All patients were operated under endo-tracheal general anaesthesia. Any Post operative complications were encountered. Post operative feeding were started on $5^{\text {th }}$ to $6^{\text {th }}$ POD, initially liquid, then gradually semisolid and solid Patients were discharged on $8^{\text {th }}$ POD. All patients were followed up 6 months to 1 year. During follow up general conditions of patients, serum albumin level, $\mathrm{Hb} \%$, and endoscopy were performed (Figure 1-3).

\section{Patient's Data}

Table 1.

Table 1: Patient's data.

\begin{tabular}{|c|c|c|c|c|c|c|c|}
\hline Sl no & Age & Sex & $\begin{array}{c}\text { Date of } \\
\text { Ingestion }\end{array}$ & $\begin{array}{c}\text { Period G00 } \\
\text { Development }\end{array}$ & Operation & $\begin{array}{c}\text { Post Operative } \\
\text { Complication }\end{array}$ & Follow-up \\
\hline 1 & $9 y r s$ & M & $15-03-2005$ & 14 days & $27 / 04 / 2005$, Gastro jejunostomy & Nothing significant & well \\
\hline 2 & $8 y r s$ & M & $15-03-2005$ & 15 days & $27 / 04 / 2005$, Gastro jejunostomy & Nothing significant & well \\
\hline 3 & 3years & M & $26-08-2010$ & 15 days & 30-09-2010, Gastro jejunostomy & Nothing significant & well \\
\hline 4 & 10years & $\mathrm{F}$ & $25-11-2010$ & 20 days & 27-12-2010, Gastrojejunostomy & Nothing significant & well \\
\hline 5 & $6 y r s$ & M & $18-02-2012$ & 14 days & 20-03-2012, Gastrojejunostomy & Nothing significant & well \\
\hline 6 & $5 y r s$ & $\mathrm{~F}$ & $18-01-2013$ & 12 days & 20-02-2013, Gastrojejunostomy & Nothing significant & well \\
\hline 7 & $7 \mathrm{yrs}$ & M & $18-02-2014$ & 15 days & 20-03-2014, Gastrojejunostomy & Nothing significant & well \\
\hline 8 & $8 y r s$ & M & $20-05-2016$ & 16 days & 22-06-2012, Gastrojejunostomy & Nothing significant & well \\
\hline
\end{tabular}




\section{Results}

Total number of patients in our study was eight, Male6 \& Femal-2. Mean age 6.378 years, range from 3 to 10 years. Type of corrosive was sulphuric acid. Intake of corrosive was accidentally. Period of development of GOO was about 18 days, range 12 to 20 days. Initially complications were oesophaitis and gastritis. But latter develop GOO within 12 to 20 days. Diagnosis by endoscopy and barium meal X-ray of upper GIT. All patients were optimized before operation. Mean operative period after ingestion of corrosive was about 30days. Mean operative time 1.5 hours. Procedure was posterior gastro-jejunostomy. No significant post-operative complications were encountered. On follow-up all patients were being well. Good general conditions, appetite, weight gain and normal life style. No re-do operation were performed [1-12].

\section{Discussion}

Gastric mucosa damage usually occurs following corrosive ingestion, along the lesser curvature and pre-pyloric region. Viscosity and specific gravity of corrosive acids are lower than that of liquid alkalis, hence acids are associated with rapid transit through the esophagus and the damage primarily occurs in the antrum and pyloric region of the stomach As a result reflex pylorospasm and stasis of acid at antrum, causes increase sensitivity of antral epithelium. Other factors that may influnces are nature of corrosive, its concentration, fasting period and position of patients during event. It is well known that acid causes damage of stomach whereas alkalis causes damage of oesophagus. Commonly available corrosive is sulphuric acid. It usually intake accidentally and this corrosive causes damage of antral epithelium. As a result 6 to $66 \%$ of patients develop gastric outlet obstruction. Initially develop gastritis then subsequently GOO and management is usually conservative avoiding a gastric lavage. Attempts at neutralizing the acids or alkalis are ill-advised and the resulting exothermic reaction from the neutralization process may do more harm than good. Similarly, there is not much role for measures to dilute the corrosive with milk, water and so forth, as the definitive extent of the injury is determined within minutes after ingestion. All patients with second degree or greater corrosive burns are given parenteral broad spectrum antibiotics. Intravenous proton pump inhibitors are also widely used with the aim of minimizing the insult to the injured gastric mucosa. Jejunostomy was performed for feeding purpose, rather than gastrostomy. The development of GOO from 6days to 6 years after corrosive ingestion and signaled by post parandial epigastric fullness, persistant non bilious vomiting, visible peristalsis and a succation splash .The sequence of events following gastric injury has been described as "delayed gastric syndrome". This is characterized by full recovery,upto two weeks after ingestion, followed by the development of early satiety, weight loss, vomiting after 2 to 6 weeks. History, clinical and radiological findings allows diagnosis. Type and timing of surgery for corrosive induced pyloric stenosis is not clearly known. There are few reports of early surgery. Emergency surgical intervention is needed if the patient develops any signs of esophageal perforation, peritonitis, or uncontrolled massive hematemesis various surgical procedures have been described to deals with obstruction of corrosive injury, such as pyloroplasty, gastrojejunostomy, partial gastrectomy and total gastrectomy. Most of the centre prefers to resect scarred stomach to avoid chance of malignant change. Although Billroth I operation is favored option. But where it is not possible, then Billroth II operation is performed. However keeping in mind, the experience of Hsu et al. [13] who described there is no evidence of malignancy arising from back ground of corrosive ingestion in more than 750 oesophageal and 20000 gastric cancers, gatrojejunostomy may be an acceptable option. This is a lesser grade of surgery compared to all forms of gastric resection, with minimal risk of stomas ulceration due to histamine fast achlorhydria in these patients (the so called "physiological antrectomy").

Ingestion of corrosive carries a high morbidity. Treatment of such patients should be staged, in order to allow full extent of scarring to develop and also to enable adequate nutrition these patients. After adequate nutrition our option is gastrojejunostomy as there is no evidence of malignancy.

\section{Conclusion}

Avoidable circumstances can be reduced by cautiousness in family as well as in every aspect of our community. For this there is a great need for adult education and for legislation to ensure correct labeling, safe packaging in child proof containers. Early surgical intervention, gives excellent result. Gastrojejunostomy is a very safe operation with minimum morbidity and excellent long-term outcome.

\section{References}

1. Kay M, Wyllie R (2001) Caustic ingestions and the role of endoscopy. J Pediatr Gastroenterol Nutr 32(1): 8-10.

2. Ozukutan BH, Ceylan H, Ertaskim I (2010) Pediatric gastric outlet obstruction following corrosive ingestion. Pedatr Surg Int 26(6): 615-68.

3. Maull KI, Osmand AP, Maull CD (1985) Liquid caustic ingestions: an in vitro study of the effects of buffer, neutralization, and dilution. Annals of Emergency Medicine 14(12): 1160-1162.

4. Hugh TB, Kelly MD (1999) Corrosive ingestion and the surgeon. Journal of the American College of Surgeons 189(5): 508-522.

5. Subbarao KSVK, Kakar AK, Chandrashekhar V, Ananthakrishnan N, Banerjee A (1988) Cicatricial gastric stenosis caused by corrosive ingestion. Aust N Z J Surg 58: 143-146.

6. Gray HK, Holmes CL (1948) Pyloric stenosis caused by corrosive substance: Report of a case. Surg Clin North Am 28(4): 1041-1056.

7. McAuley CE, Steed DL, Webster MW (1985) Late sequelae of gastric acid injury. Am J Surg 149(3): 412-415.

8. Maull KI, Osmand AP, Maull CD (1985) Liquid caustic ingestions: an in vitro study of the effects of buffer, neutralization, and dilution. Annals of Emergency Medicine 14(12): 1160-1162. 
9. Tekant G, Eroglu E, Yesildag E, Emir H, Buyukunal C, et al. (2001) Corrosive injury-induced gastric outlet obstruction: A changing spectrum of agents and treatment. J Pediatr Surg 36: 1004-1007.

10. Hwang TL, Chen MF (1996) Surgical treatment of gastric outlet obstruction after corrosive injury-can early definitive operation be used instead of staged operation? Int Surg 81(2): 19-21.

11. Postlethwait RW (1983) Chemical burns of the esophagus. Surgical Clinics of North America 63(4): 915-924.

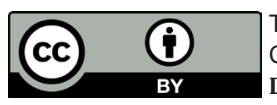

This work is licensed under Creative Commons Attribution 4.0 License DOI: 10.19080/ARGH.2018.09.555767
12. Zamir O, HOD G, Lernau OZ, Mogle P, Nissan S (1985) Corrosive injury to stomach due to acid ingestion. Am surg 51(3): 170-172.

13. Hsu C, Chen C, Hsu N, Hsia J (1997) Surgical treatment and its long term result for caustic-induced prepyloric obstruction. Eur J Surg 163(4): 275-279.

\section{Your next submission with JuniperPublishers will reach you the below assets}

- Quality Editorial service

- Swift Peer Review

- Reprints availability

- E-prints Service

- Manuscript Podcast for convenient understanding

- Global attainment for your research

- Manuscript accessibility in different formats

( Pdf, E-pub, Full Text, audio)

- Unceasing customer service

Track the below URL for one-step submission https://juniperpublishers.com/online-submission.php 